This article is (c) Emerald Group Publishing and permission has been granted for this version to appear here (http://epress.lib.uts.edu.au/research/handle/10453/10312). Emerald does not grant permission for this article to be further copied/distributed or hosted elsewhere without the express permission from Emerald Group Publishing Limited.' 


\title{
A Review of Australian Audit Pricing Literature
}

\author{
Andrew C. Ferguson \\ School of Accounting \\ University of New South Wales
}

\begin{abstract}
This paper provides a review of the extensive contributions made to the audit pricing literature by researchers utilizing Australian data. Recent United States [hereafter US] regulatory requirements under the Sarbanes Oxley Act (Section 102) have mandated disclosure of audit fees. As such this is a useful occasion to review the existing Australian audit pricing research, since the audit fee disclosure advantage once enjoyed by Australian researchers has now effectively dissipated. Beginning with the origins and genesis of audit pricing research in Australia, this review then discusses the key contributions to the literature over time. It concludes with some brief discussion of potential research directions.
\end{abstract}

Keywords: Audit pricing, Audit quality, Auditor industry specialization

\subsection{Introduction}

Australian researchers have for many years been at the forefront of the audit pricing literature. This situation has in large part resulted from the public disclosure of audit fee data in the annual reports of listed Australian companies. Since audit fees have not been disclosed in the US until 2002, Australian researchers have held a comparative advantage over their US counterparts, who were previously forced to

An anonymous referee is thanked for suggestions 
acquire data through survey methods, or by direct approach to the accounting firms themselves. Both these methods have proved unreliable in terms of data supply on an ongoing basis, and thus constrained US research output in this area.

The post-Enron disclosure regime in the US now provides for similar audit fee disclosure to that mandated in AASB $101 .{ }^{1}$ Since the Australian audit fee data source advantage has now disappeared, this appears to be a useful occasion to review the existing Australian audit pricing evidence, and to suggest some possible future directions for Australian researchers. The review is also timely in light of recent regulatory interest in the public accounting profession including The Panel on Audit Effectiveness (2000) and the Sarbanes-Oxley Act (2002) in the US, and the Ramsay Report (2001) and the CLERP Audit Reform and Corporate Disclosure Act (2004) in Australia. Regulatory interest has seen the practise of auditing placed under the microscope.

The review is structured as follows: In the Section 2, the origins of the audit pricing model and the theory of audit quality are discussed. Section 3 includes a review of the 'early' Australian literature focussed on product differentiation and pricing premiums for large audit firms. Section 4 examines pricing premiums for the industry specialist auditors. Section 5 extends discussion in Section 4 and overviews recent literature on industry specialist premiums at the local office level. Finally in Sections $6.1-6.3$ some possible future research directions are briefly discussed.

\footnotetext{
${ }^{1}$ It is noted that AASB 101, consistent with provisions in the Corporate Law Economic Reform Program [hereafter CLERP] Audit Reform and Corporate Disclosure Act $24^{\text {th }}$ June 2004, requires enhanced disclosure of monetary payments to auditors for differing types of non-audit services such as tax, consulting, IT, audit related, and accounting and due diligence. This is significant since the Sarbanes Oxley Act (2002) Section 201 effectively prohibits an auditor from performing all other types of non-audit services apart from tax in the US. Thus, the allowance of the auditor to (i) perform, and for the client to (ii) disclose differing types of non-audit services in Australia maintains an interesting non-audit fee advantage for Australian researchers. Implications of this enhanced disclosure are discussed further in the Section 6.2 'Auditor Independence' where possible future research directions are discussed.
} 


\subsection{Origins of the audit pricing model}

Simunic (1980) provides the theoretical underpinning for the most often applied audit fee model used in economics of auditing research. For the auditee, Simunic suggests that an audit functions as a type of insurance, the benefits of which arise from liability avoidance to financial statement users (shareholders, creditors) in the event of litigation. This theoretical approach also explains the relative demand for internal versus external auditing. Simunic argues that a substitution effect occurs between internal and external auditing, dependent on the relative strength of the client's internal controls.

From the supply perspective, the key determinants of audit prices are those factors deemed to contribute to an auditors' potential loss exposure arising from such litigation. To identify these drivers of potential auditor loss exposure, Simunic (1980) adopted an inductive research approach. Discussions were held with representatives of large audit firms, and also providers of professional liability insurance. ${ }^{2}$ From these discussions, a number of factors were identified as supply side determinants of loss exposure. These included (a) the size of the auditee, (b) the complexity of the auditee's operations, (c) the risk of the auditee's operations, and (d) the industry of the auditee. The empirical proxies developed by Simunic for each determinant form the basis of the audit fee model, applied in the majority of subsequent audit pricing studies both in Australian and abroad.

Whilst Simunic (1980) is credited with the theoretical development of the audit fee model, the paper also makes major empirical contributions. A key empirical issue addressed in the study is whether assumptions of price competition in the audit

\footnotetext{
${ }^{2}$ Throughout this paper, the term large auditors merely refers to any combination of Big 8, Big 6 or Big 5 auditors, whilst the term small auditors refers to the non-Big 8, non-Big 6 or non-Big 5 auditors respectively.
} 
market are valid following the merger activity that saw the formation of the Big $8 .^{3}$ To examine this issue, Simunic partitions the sample based on client size, with the assumption of price competition in the market for small audits providing a benchmark for comparison with the increasingly concentrated market for larger client audits. The results indicate no significant differences in the auditor type (large versus small) coefficients across the two sub-samples, indicating the assumption of price competition throughout the market cannot be rejected. In addition, negative co-efficients on the large audit firm indicator variable across the full sample is argued to be a function of economies of scale benefits to larger auditors. This is suggestive of larger auditors charging lower fees, although this finding has not been replicated in subsequent audit pricing studies. Structural issues raised in Simunic (1980) would influence later audit pricing research in Australia.

The other key theory contribution impacting subsequent Australian audit pricing studies was DeAngelo (1981). ${ }^{4}$ DeAngelo developed the theoretical basis for the existence of audit quality, and its relationship with auditor size. DeAngelo defined audit quality as: the probability that an auditor will discover a breach in the client's accounting system, and

(b) the probability that this breach will be reported.

DeAngelo (1981) provides two supply side arguments supporting a relationship between auditor quality and auditor size. First, large auditors make

\footnotetext{
${ }^{3}$ Such concerns about consolidation amongst accounting firms and their dominance in the market for large client audits are documented in the Subcommittee on Reports (1976) commonly referred to as 'The Metcalf Report'. Interestingly, consolidation concerns have once again been raised in Sarbanes Oxley Act (2002), where a separate inquiry was held in to market concentration and its effects. ${ }^{4}$ Discussion of the audit quality literature is necessarily limited in this review, and readers should consider the rich literature residing outside 'economics based' studies in the form of the behavioral literature. In addition, it is also acknowledged that there are contextual issues raised in the literature such as the implications of audit switching on audit pricing that could easily be the subject of a separate review.
} 
significant investments in audit technologies, undertake more rigorous staff training, and have higher expenditures on promotion and advertising. ${ }^{5}$ Such investments give rise to greater reputation capital, which is reflected in higher partner capital contributions. Second, DeAngelo suggests implicit benefits of audit incumbency produce incentives for large auditors to provide higher quality audits. Benefits of incumbency include the elimination of client specific start up costs incurred by auditors as they 'get to know' new clients. On the demand side, clients are faced with switching costs (principally search costs) incurred when changing auditors. As a result of the existence of these 'joint costs', a bilateral monopoly exists, and the larger the auditors' client base, the larger the quasi rents at stake should the auditor produce a poor quality audit. The auditor quality - size relationship posited by DeAngelo, and competition issues raised in Simunic (1980) would motivate much of the subsequent Australian audit pricing research.

\subsection{Early Australian research: Product differentiation and pricing premiums for}

\section{large audit firms}

Following Simunic (1980) and DeAngelo (1981), the early research literature using Australian data namely Francis (1984), and Francis and Stokes (1986) sought to examine whether product differentiation might be a factor in audit pricing. Francis (1984) develops theoretical arguments for client demand for higher quality audits based on agency theory. The agency theory argument suggests that shareholders impose tighter monitoring on those managers who are viewed as being more opportunistic, or on firms that suffer from higher perceived or real agency costs. If

\footnotetext{
${ }^{5}$ Higher expenditure on promotion and advertising is likely to lead to greater perceived audit quality.
} 
tighter monitoring is demanded by shareholders, one solution would be to choose a higher quality auditor.

Francis (1984) argues that if audit quality is not homogeneous, the implicit assumption of collusive behaviour where concentration of audit firms is high is incorrect. The reason is smaller auditors might choose not to invest to build the necessary reputation to service larger clients. This will account for the high concentration of audit firms in the large client market segment, rather than smaller auditors being 'forced out'. In addition, since large auditors supply higher quality audits, they will also supply higher priced audits, given differentiated demand and a competitive market. These assertions form the basis of the empirical tests undertaken. Francis (1984) specifies the audit pricing model as follows:

$$
\begin{array}{cc}
\text { LAF }=b_{0}+b_{1} \text { LTA }+b_{2} \text { SUB }+b_{3} \text { CATA }+b_{4} \text { QUICK }+b_{5} \text { DE }+b_{6} \text { ROI }+ \\
b_{7} \text { OPINION }+b_{8} \text { YE }+b_{9} \text { LOSS }+b_{10} \text { AUDITOR }+e
\end{array}
$$

where:

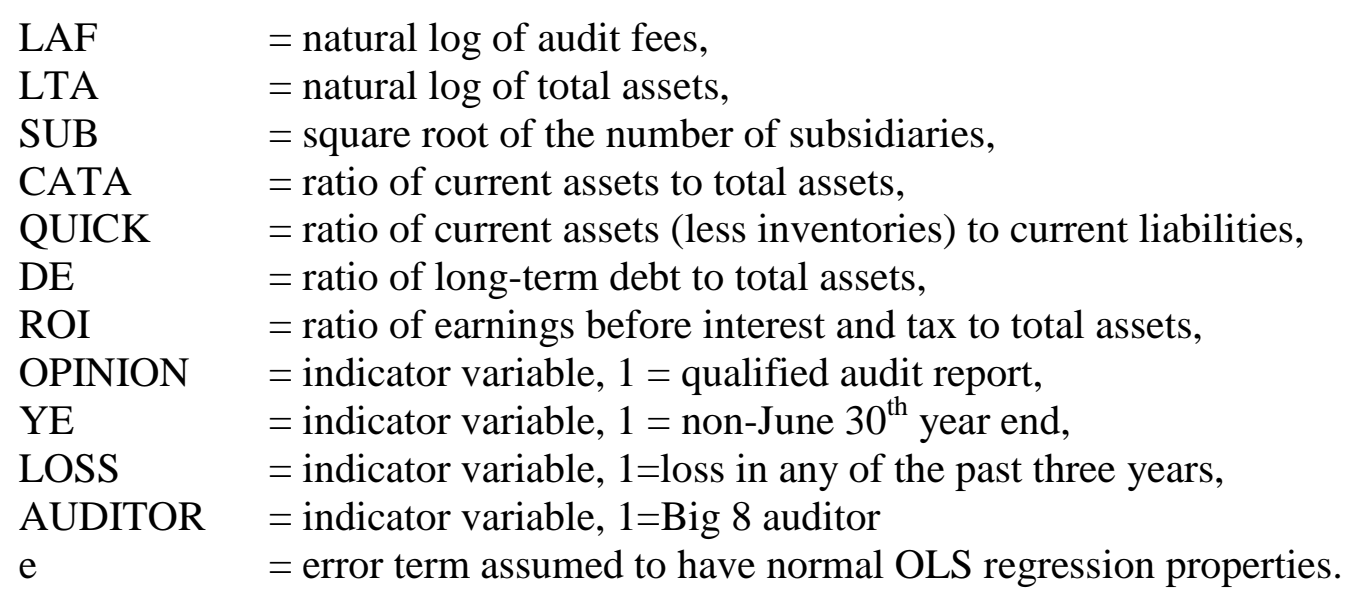

Francis (1984) selects a sample of 150 Australian listed companies over each year from 1974 to 1978 (30 per year), and runs the above ordinary least squares regression model in pooled cross section. After deleting 14 financial institutions, the remaining sample is split on median total assets, and the test run in both the large and 
small client segments. The results indicate no structural differences between the two models, with the sign of the auditor indicator positive and significant in both cases. This indicates higher audit fees to the Big 8 in both the large and small segments, consistent with assertions of product differentiation to the Big 8. Since competition is the maintained assumption in the small client segment, the consistency of price premiums to the Big 8 across the two segments is not suggestive of collusive or monopolistic pricing by large auditors.

Francis and Stokes (1986) revisit the competition issue, and argue that the differing empirical results (in terms of fee premium existence) between Simunic (1980) and Francis (1984) could be due to respective differences in auditee size across the two studies. By selecting a bigger sample of large and small companies, Francis and Stokes sought to provide further evidence on the competition issue. Using the same pricing model as Francis (1984), Francis and Stokes find price premiums to the Big 8 in the small client segment, but no Big 8 premium in the large client segment. This is interpreted as evidence of product differentiation to the Big 8 in the small client market. In the large client segment, the failure to identify Big 8 premiums is interpreted as the co-existence of Big 8 product differentiation, along with diseconomies of scale to the non-Big 8 for large client audits. The diseconomies are argued to force up prices of the small auditors, offsetting product differentiation premiums to the large auditors, resulting in no observed Big 8 premium.

\subsection{Pricing premiums for industry specialist auditors}

One of the most widely cited papers in the audit pricing literature is Craswell, Francis and Taylor (1995) [hereafter CFT]. CFT examine Simunic (1980)'s assertions that the pricing of audits may differ according to the industry of the auditee. CFT suggest that 
company and industry specific factors result in cross sectional differences in monitoring demand, including demand for industry specialists. CFT argue that the supply of higher quality auditors in the form of industry specialists is merely a response to clients who demand higher quality monitoring as a function of their increased agency costs. Thus the demand for quality-differentiated audits - both brand name audits and industry specialist audits - is grounded in agency theory (CFT, p. 299). This differential demand for auditing leads auditors to undertake investments enabling the supply of differentiated audit quality in the form of Big 8/non-Big 8 differentiation, and within Big 8 differentiation through industry specialization.

If Big 8 auditors make these investments, they will require a normal rate of return on those investments (CFT, p. 301). This should be reflected in higher fees for large compared to small auditors and higher fees for specialist large auditors compared to non-specialists. CFT utilize a sizeable sample of 1484 ASX listed companies from 1987, and apply a cross sectional OLS regression model. The pricing model applied is the same as Francis (1984) with two slight modifications. First, the variable 'Foreign', (which is the proportion of subsidiaries that are foreign subsidiaries), is included as a further complexity control. Second, in addition to a Big 8/nonBig 8 indicator, another test variable coded ' 1 ' for industry specialist Big 8 auditor and coded ' 0 ' for a non-specialist Big 8 auditor is included in the model.

On top of a brand name premium, CFT find a $34 \%$ premium to auditor industry specialists. CFT's findings raise two interesting issues in terms of their interpretation and generalisability. First, an important point to note is that specialists were defined as those auditors holding a $10 \%$ market share of either clients or fees in 'specialist' industries. However, the presence of the fee premium at the $10 \%$ share is not replicated for a tighter definition of specialist at the $20 \%$ level. CFT suggest some 
caution in interpreting their result, as it may be a product of a data artefact. It also raises the issue of whether the presence of economies of scale 'kick-in' at somewhere between the $10 \%$ and $20 \%$ market share level, mitigating any product differentiation premiums at the higher market share threshold.

A second issue is the location of the observed premium. The premium in CFT is found for clients in 'specialist' industries; with specialist industries defined using the Craswell and Taylor (1991) methodology. For an industry to be defined as a specialist industry as per Craswell and Taylor, it must have a minimum of 30 companies. The choice of this threshold appears arbitrary. These issues are examined further by Ferguson and Stokes (2002).

Ferguson and Stokes (2002) [hereafter FS] investigate audit pricing evidence following the CFT study. Their analysis incorporates audit pricing implications following the 1989 audit firm mergers forming the Big 6, and also around the 1997 Price Waterhouse and Coopers \& Lybrand merger precipitating the formation of the Big 5. FS pose the following two questions; Do brand name premiums persist following the two rounds of merger activity after CFT? Do industry specialist premiums persist after the same two rounds of merger activity? To test these issues using a more recent sample, audit fee and other necessary data from hardcopy annual reports and other sources for the years 1990, 1992, 1994, 1998 were acquired. The brand name and specialist hypotheses are re-examined using similar market share based definitions of specialization as CFT. Additional market share sensitivities are also tested in light of the merger activity, and associated concentration effects.

The results documented in FS indicate that the general brand name distinction between large and small auditors is present. Second, consistent with the prior CFT findings, when tests of specialist premiums at various levels of market share are 
undertaken, they produce only mixed results. For example, FS tests of specialist premiums using either fees or clients at the $10 \%$ and $20 \%$ cut-offs, are observed in only two out of four years. As a final test, the logic of the auditor quality/industry specialist argument is extended through tests for the existence of premiums paid to auditor industry leaders. Industry leadership is arguably more unequivocal and unambiguous signal of reputation than tests based on the arbitrary market share categories first adopted in CFT. ${ }^{6}$ Results of the tests of industry leadership identify a change in the strength of the audit industry leader co-efficients over time. In earlier years (1990 - 1992), evidence of audit industry leader premiums is reported. However, by 1994, this premium has weakened to the extent that when tests are run in specialist industries, no evidence of leader premiums is found. By 1998, no evidence of leader premiums is present in either tests within specialist industries or in tests across all industries. However, the extent to which the weakening of leadership premiums may be due to economies of scale benefits is hard to determine.

Two further findings in FS are noteworthy. First, sensitivity tests show that when non-audit service fees are added to the dependent variable, the leadership premiums where observed, disappear. This indicates that audit pricing may be sensitive to potential non-audit service revenues. ${ }^{7}$ Second, in years when leadership premiums are observed, when each individual auditor is excluded one at a time, the exclusion of KPMG results in no premium being observed. ${ }^{8}$ This suggests that

\footnotetext{
${ }^{6}$ A number of anecdotal reports, as well as the marketing literature, discuss the reputation value of a 'leadership position'. For example, Hellofs and Jacobsen (1999) cite efforts by Ford to maintain the market share required to be the top-selling car in the US They suggest:

"To be able to advertise "Taurus - America's Best-Selling Car Again," Ford resorted to offering $\$ 1000$ rebates for the Taurus to protect its lead over Honda's Accord as the number-one-selling car in the United States" (Naughton 1997).

${ }^{7}$ These tests are consistent with those run by CFT p316 'Jointness of audit and nonaudit fees'.

${ }^{8}$ Interestingly, Gramling and Stone (2001) cite prior studies suggesting that KPMG was the first Big 5 auditor to implement organizational restructuring along industry service lines.
} 
leadership fee premiums are sensitive to non-audit fees and possibly individual auditor brand name effects.

In summary, the weakening of reported leadership premiums by 1994, and subsequent disappearance by 1998 raises further issues about the nature and existence of audit fee premiums. One question that remained unanswered in FS is whether the premium is more likely to occur at the local office level, as opposed to firm - wide or nationally. ${ }^{9}$ This question is considered by Ferguson, Francis and Stokes (2003) [hereafter FFS (2003)].

\subsection{Industry specialist premiums at the local office level}

FFS (2003) extend the investigation by FS of large audit firm product differentiation. FFS consider two contrasting ways of typifying the operations of Big 5 accounting firms. ${ }^{10}$ First they consider the 'firm-wide' perspective, where the operations of the Big 5 are viewed on an aggregated or national level. Under this view little differentiation is likely to exist across individual offices and in terms of audit pricing, a firm-wide measure of expertise is appropriate. In contrast, under the 'office level' perspective, each office within the network retains local idiosyncrasies. Since the audit contract is conducted, administered and most commonly signed-off on office specific letterhead, it is argued that the local office level constitutes an appropriate unit of analysis in its own right. Under the office-level perspective, expertise resides in human capital and experience of staff in each office. Thus a localised measure is relevant to capture industry expertise in audit pricing.

\footnotetext{
${ }^{9}$ A caveat on this test is that there is no way of knowing if only the top ranked firm earns a premium. If more than one firm in an industry is perceived by the market as holding a specialization, then this approach will misclassify some specialists as non-specialists, and thus weaken the design and statistical tests.

${ }^{10}$ This approach is motivated by a prior study, Francis, Stokes and Anderson (1999) who used US data.
} 
FFS (2003) examine industry leading and second ranked auditors both nationally and locally, to counter any misspecification that might result from industry expertise residing outside the leading firm. The evidence indicates that auditors who are one of the top two ranked firm's nationally and also local industry leaders, enjoy $24 \%$ higher fees. However, where the top two ranked firms nationally are not the local industry leader, no fee premiums are earned. Thus, FFS (2003) conclude that an auditor must hold joint city-level and national industry leadership to generate premiums for industry expertise. This implies the absence of any positive network externality across offices.

Investigation of fee determination at the local office level is extended further by Ferguson, Francis and Stokes (2005) [hereafter FFS (2005)]. FFS (2005) examine whether results in FFS (2003) might be confounded by the presence of city-specific overall market leadership effects. FFS (2005) reaffirm that joint local and national auditor expertise is valued by audit clients. In addition, they find evidence that overall city-specific market leadership also matters in fee determination, although at weaker significance levels. Their results highlight the importance of both city-specific industry leadership, and city-specific overall leadership in differentiating auditors.

\subsection{Possible research directions}

This review has focussed on the significant contribution made by audit pricing studies based on Australian audit fee data over the last two decades. This period corresponds with the competitive advantage in the form of audit fee data availability Australian researchers have enjoyed vis-a-vis those in the US. A 'level playing field' with regard to audit fee disclosure raises the question of the likely direction of future Australian enquiry. Fortunately the dynamic state of market structure, coupled with 
regulatory interest in accounting firms point to continuing opportunities. Whilst current US studies are likely to be directed at least in part by issues raised in the prior Australian empirical research, there will be an ongoing role for Australian research effort in replication of US audit pricing studies. The international interest in such replication style papers will rest on the importance to the literature of out of US sample evidence. In addition to replications, the following areas come to mind as possible future research areas and constitute by no means an exhaustive list.

\subsection{Consolidation issues}

Regulatory concerns about heightened concentration in the market for audit services represents something of an 'old chestnut', and arguably first motivated Simunic (1980). Today however, it remains an important issue facing the profession as regulators across the globe continue to express concerns about concentration and its impact on competition. ${ }^{11}$ For example in a recent Australian Federal Treasury policy paper it is suggested:

'In short, just 10 firms service nearly 80 per cent of the market. The remainder is spread across firms that audit less than three listed clients. With such concentration, companies face a restricted pool of audit firms with experience in auditing listed companies. Where one of the major audit firms is providing non-audit services to a company, the pool of possible providers of audit services may be even more limited.

\footnotetext{
${ }^{11}$ For example, regulatory bodies in the US have raised recent concerns about the effects of increasing concentration amongst large audit firms through Sarbanes Oxley (2002).
} 
Choice would be further restricted if a company did not wish to contract audit services from a firm that audited a major competitor, 12

Since the collapse of Arthur Andersen and its subsequent merger with the Ernst \& Young in Australia, the number of top-tier competitors both in Australia and internationally has been reduced to four. Regulatory interest regarding aspects of concentration and competition in the audit market is being fuelled by the perceived profitability of the Big 4. A number of anecdotal reports are consistent with this assertion. ${ }^{13}$ Consequently, research examining potential for collusive behaviour and indicators of collusion such as industry profitability appear to be of interest. A point to note is that US fee disclosure does not extend back prior to the demise of Arthur Andersen in 2001, so any study examining fee effects prior to and after this event will benefit from data outside the US

\subsection{Auditor independence}

Independence concerns arising from joint supply of audit and non-audit services have been heightened by recent corporate collapses. Early Australian evidence on this issue is provided by Barkess and Simnett (1994) who also examine the determinants of non-audit service fees. Barkess and Simnett identify no relationship between audit qualifications and non-audit service fees. Wines (1994) also examines auditor supply of non-audit services and propensity to modify audit opinions, and finds that auditors sourcing more non-audit services from clients are more likely to provide a clean opinion. More recently Craswell (1999) finds that non-audit services do not pose

${ }^{12}$ CLERP Paper No.9: Proposals for Reform - Corporate Disclosure. Part 3: The market for audit services.

${ }^{13}$ See for example 'Big Four, Big Worries' BRW 10.04.03, and 'Bloodied but Rich' Business Week 03.06.02 pp. $74-75$. 
independence threats. Thus the bulk of Australian evidence does not indicate independence threats through non-audit service provision.

In terms of further effort in this area, researchers might consider that recent audit firm restructuring has seen consulting divisions spun-off, which arguably resolves some of the perceived independence threat. Consequently, research effort on non-audit services using Australian data will most likely evolve more along the lines of recent US literature such as Whisenant, Sankaraguruswamy and Raghunandan (2003). This study examines whether audit and non-audit services fees are simultaneously determined. This approach has not been replicated in Australia, and given the non-audit services sensitivity results reported in FS, joint determination represents an attractive research question to be applied to Australian data.

As observed in Footnote 1, research questions involving non-audit services will also be encouraged by enhanced non-audit fee disclosure emanating from the CLERP Audit Reform and Corporate Disclosure Act (2004). This requires a breakdown of amounts paid to auditors for different types of non-audit services such as tax, consulting, IT, audit related, accounting and due diligence to be provided in notes to the financial accounts. Interesting questions such as the relationship between the magnitude of certain types of non-audit services and audit fees remain underresearched. Such research questions using Australian non-audit fee disclosure will have the added attractiveness due to the effective US prohibition of all non-audit services apart from tax under Section 201 of the Sarbanes Oxley Act (2002). Thus whilst the US now has comparable audit fee disclosure to Australia, we maintain a disclosure advantage in terms of non-audit fees. 


\subsection{Measurement Issues}

A final suggestion relates to the potential for improvements in the audit quality proxies adopted in audit pricing studies. Gramling and Stone (2001) contains a useful summary including discussion of problems relating to measurement of industry expertise. Gramling and Stone list the three methods typically adopted in the literature including: (1) industry market share as a proxy for industry expertise, (2) percentage of an audit firm's revenue in an industry relative to total revenue across all industries and (3) specialist measures based on self proclaimed industry specialization on accounting firm web-sites. Each of these measures of industry specialisation has potentially serious problems. For example, using audit fees to construct market share metrics to define specialisation or industry leadership creates a potential endogeneity problem, since the dependent variable is a log of audit fees. This highlights a more general problem faced by researchers in the economics of auditing field which is the development of valid measures of the audit quality construct.

One approach might be to make use of capital market assessments to validate existing audit quality measures. An example using Australian data is Ferguson and Matolcsy (2004), who examine audit quality measures in a post-earnings announcement drift context. ${ }^{14}$ Ferguson and Matolcsy examine large versus small audit firm, industry specialist, and auditor industry leader dummies - the same audit quality metrics applied in FS. Interestingly, Ferguson and Matolcsy find differing capital market reaction when partitions are undertaken within the Big $6 / 5$ auditors themselves. This result is not unsurprising given FS report that the industry specialist

\footnotetext{
${ }^{14}$ Another recent example of applying audit quality metrics in a capital market setting is StevensonClarke and Hodgson (2004) who examine Audit Quality and both earnings and cash response coefficients. They find that the use of a Big 5 auditor enhances the perceived credibility of reported earnings for industrial companies, but not mining firms.
} 
premium disappeared when KPMG was excluded from the sample, implying that specialist premiums were impacted by individual auditor brand name effects.

Two points emerge from Ferguson and Matolcsy (2004). First, it is likely that audit pricing research will be increasingly directed at identifying differences within the Big 4 as opposed to simple comparisons of large and small auditors. Second, novel ways of validating and assessing audit quality metrics are likely to be of interest to the both practitioners and researchers alike. 


\section{References}

Barkess, L., and R. Simnett. (1994), 'The provision of other services by auditors: Independence and pricing issues', Accounting and Business Research, vol. 24, pp. 99-108.

Craswell, A. (1999), 'Does the provision of non-audit service impair independence?', International Journal of Auditing, vol. 3, pp. 29-40.

Craswell, A., and S. Taylor. (1991), 'The market structure of auditing in Australia: The role of industry specialization', Research in Accounting Regulation, vol. 5 , pp. 55-77.

Craswell, A., J. Francis, and S. Taylor. (1995), 'Auditor brand name reputations and industry specializations', Journal of Accounting and Economics, vol. 20 (3), pp. $297-322$.

DeAngelo, L. (1981), 'Auditor size and auditor quality', Journal of Accounting and Economics, vol. 3 (3), pp. 183-199.

Ferguson, A. and Z. Matolcsy. (2004), 'Audit quality and post earnings announcement drift', Asia Pacific Journal of Accounting and Economics, vol. 11 (2), pp. 121137.

Ferguson, A., J. Francis and D. Stokes. (2003), 'The effects of firm-wide and office level industry expertise on audit pricing', The Accounting Review, vol. 78 (2), pp. $429-448$.

Ferguson, A., J. Francis and D. Stokes. (2005), 'What matters in audit pricing Industry specialization or overall market leadership?', Accounting and Finance, Forthcoming.

Ferguson, A. and D. Stokes. (2002), 'Brand name audit, industry specialization and leadership premiums post the Big 6 and Big 8 mergers', Contemporary Accounting Research, vol. 19 (1), pp. 77-110. 
Francis, J. (1984), 'The effect of audit firm size on audit prices: A study of the Australian market', Journal of Accounting and Economics, vol. 6 (2), pp. 133151.

Francis, J., and D. Stokes. (1986), 'Audit prices, product differentiation, and scale economies: Further evidence from the Australian audit market', Journal of Accounting Research, vol. 24 (2), pp. 383-393.

Francis, J., D. Stokes, and D. Anderson. (1999), 'City markets as a unit of analysis in audit research and the re-examination of Big 6 market shares', Abacus, vol. 35 (2), pp. 185-206.

Gramling, A.A., and D.N.Stone. (2001), 'Audit firm expertise: A review and synthesis of the archival literature', Journal of Accounting Literature, vol. 20 (1), pp. 1-29.

Hellofs, L.H., and R. Jacobson. (1999), 'Market share and customers' perceptions of quality: When can firms grow their way to higher versus lower quality?', Journal of Marketing, vol. 63, pp. 16-25.

Naughton, K. (1997), 'Taurus may tumble from the top', BusinessWeek, January 20, p. 4.

Public Oversight Board, (2000), 'The panel on audit effectiveness final report', September $6^{\text {th }}$, Stanford CT.

Ramsay, I. (2001), 'The independence of Australian company auditors: Review of current Australian requirements and proposals for reform', Report to the minister for financial services and regulation, The University of Melbourne.

Simunic, D. (1980), 'The pricing of audit services: Theory and evidence', Journal of Accounting Research, vol. 18 (1), pp. 161-190. 
Stevenson-Clarke, P., and A Hodgson. (2004), 'Estimating the value added by Big 8/6/5 auditors using linear and nonlinear earnings and cash response coefficients', Accounting Research Journal, Forthcoming.

Subcommittee on Reports. (1976), 'Accounting and management of the commission on government operations, United States Senate', The Accounting Establishment: A Staff Study, Washington D.C., Government Printing Office.

Whisenant, S., S. Sanaraguruswamy and K. Raghunandan. (2003), 'Evidence on the joint determination of Audit and non-audit fees', Journal of Accounting Research, vol. 41 (4), pp. 721-744.

Wines, G., (1994), 'Auditor independence, audit qualifications and the provision of non-audit services: A note', Accounting and Finance, May, pp. 75-86. 